\title{
A Short Code of Underground Water.
}

While the Conservation Commission of California was preparing the Water Bill which this year's legislature passed ${ }^{1}$ (but whose operation has been stayed by referendum, pending submission to popular vote), the present writer was requested by the Commission to offer in writing suggestions for such a bill. These suggestions were not acted upon by the Commission and form no part of the bill presented to the legislature, nor of the statute passed. Among these suggestions were some "Underground Water Clauses," intended to codify in simple form the law now existing upon that subject. and they are given herewith, a little revised for the purpose of this article. They are meant to be a statement of the new doctrine which the Supreme Court of Cailfornia, speaking chiefly through Mr. Justice Shaw, has recently established, acting for the public welfare, and which has recognition as an advanced position in the law of underground water. The object of putting such clauses into a statute would have been to advance the public facility in finding the law, and, in a few instances where the law is doubtful, to choose by statute between different possible views.

\section{A. General Principles.}

1. Property in Underground Water. Underground water in its natural state is not and can not be the subject of private ownership. A right to the continued existence and use of an underground water-supply may exist in a private person and constitutes a water-right. The continuance and use of the water-supply, and not the water itself, constitutes the subject of the "water-right." No portion of the underground water becomes, itself, private property until reduced to possession by a structure confining it under private control, such as a well, and then property can be ásserted only in the particular portion of water confined therein at any specific moment of time.

1 Stat. 1913 p. 1012. 
2. Consolidated Underground and Surface Water-Supplies. A definite body of water upon the surface, and the underground water proximately connected therewith in natural occurrence, constitute a consolidated underground and surface water-supply. A surface water-course with the underground water tributary thereto, likewise a surface water-course with the subflow of underground water immediately surrounding and beneath it and moving with it in a space reasonably well defined, likewise a definite basin of underground water with a stream entering and depositing water into the basin by seepage from the stream, or with the stream leaving the basin and receiving water by seepage from the basin, are consolidated underground and surface water-supplies. The rights hereinafter stated extend to the whole and every part of a consolidated surface and underground water-supply in favor of claimants located upon any part, without distinction between the surface part and the underground part.

3. Access Necessary. No one may enter private property against the protest of its owner, nor build works or exercise rights-of-way thereon against the protest of the owner, except by grant, condemnation, or prescription. A lawful right of access to the supply is necessary before rights therein can be exercised.

\section{B. Overlying Landowners Between Themselves.}

4. Overlying Landowners Have Natural Access. Owners of land situated adjacent to any part of an underground watersupply, since they may reach the supply without entering lands of others, have natural access to the underground watersupply by virtue of their natural situation. They are called "overlying landowners," and the word "overlying" includes "adjacent," and the word "adjacent" includes "overlying."

5. Local Overlying Land Defined Between Overlying Landowners. Local overlying land entitled to the equality of right below mentioned is any continuous tract in the ownership of one owner (or in joint or common tenancy) at the time of use thereon, the surface of which land all lies within the same watershed and overlies or adjoins the same natural underground supply. 
6. Overlying Landowners have a Common Right between Theinselves. Water-rights in an underground water-supply exist in all overlying landowners. The underground water is a common supply in which all who, by such natural situation, have access to it, have a common right, as part and parcel of the overlying lands. Persons owning an estate in the land less than the fee simple may maintain actions to protect their estate, upon the same terms as owners of the fee simple, such relief terminating, however, upon the termination of the estate in the land.

7. Between Overlying Landowners there is an Equality of Right. All overlying landowners are equal in right to use each his own overlying land. Their rights are correlative, interdependent and adjustable for their common benefit. In order that this equality of right may be preserved, the overlying landowner who first uses the underground water-supply has no greater rights than other overlying landowners, nor is the right of any overlying landowner to the use and continuance of a supply of water beneath his ground lost by non-use. It can be lost only by grant, condemnation or prescription.

8. This Equality of Right entitles each Overiying Landowner to make Reasonable Use of his own Overlying Land. Each overlying landowner is entitled to make all reasonable, as opposed to excessive, efforts to promote the use of his own overlying land, and if harm or damage results, from such reasonable use, to another overlying landowner, it is not wrongful. But if any overlying landowner's acts are excessive, any detriment to the overlying land of another, or to its value or water-supply or uses, present or future, is wrongful, even though complainant is not himself actually using water at the time.

9. What is a Reasonable Use between Overlying Landowners rests in the Sound Discretion of the Trial Court. What is a reasonable use between overlying landowners upon their overlying lands rests in the sound discretion of the trial court or jury from all the evidence and circumstances surrounding the case, the parties, their lands, and the watersupply. The trial court or jury are to hear all the evidence and give their best general impression as reasonable men. Being discretionary with judge or jury, their finding can be 
questioned only in clear cases of abuse. The burden of proof between overlying landowners is apon the complainant to show that the act of the overlying landowner complained of is excessive. Any use by one overlying landowner on his overlying land is presumed to be reasonable until the contrary is shown by a preponderance of evidence.

10. Apportionment of Deficiency between Overlying Landowners. If the supply is insufficient for the full uses of all contesting overlying landowners, the trial court sitting in equity may establish a reasonable use for each. by apportioning to each a continuous use to the fullest capacity of his land for a restricted period of time, or by assigning to each a specific quantity of water without restriction as to time of the use, or the apportionment may take the form of a combination of the two forms just mentioned, or may be in any other form that the circumstances may warrant, in the sound discretion of the trial court. The party seeking apportionment must furnish evidence of all the material circumstances surrounding the parties, the land, and the waters, and has the burden of showing what would be reasonable for each, failing which proof he will have failed to make out a case for such relief, and an apportionment will be denied. In apportioning water between overlying landowners each will be allotted such proportion of quantity or use (in addition to what may be reasonable for present uses) as may be reasonably required by him in the future upon his overlying land, whether he is now using the water or not; but in case he is not now using the water the apportionment will not be accompanied by an injunction, until such time as his use is about to begin.

11. Apportionment is confined to Contesting Parties. In apportioning underground water between overlying landowners the share to be given to each will be ascertained by allotting the entire supply among the contestants, irrespective of the fact that there be other parties entitled to share in the supply who have not taken part in the litigation or other contest. Such an apportionment, however, is not binding upon such outstanding owners within the prescriptive period, and against them confers only possessory rights, (as in sections 16 to 25 below specified), subject to defeasance by them to the extent of any surplus which the apportionment among the smaller number would give to each over what he would be entitled to 
in case the apportionment were to consider the larger number. In all cases the trial court has discretion to order any or all outstanding landowners overlying the supply, or any other claimants thereto, to be made parties to the suit, or they may intervene voluntarily, as in other cases in equity.

12. Domestic Use is a Preferred Use between Overlying Landowners. Domestic uses between overlying landowners upon their overlying lands are preferred to other uses, and in case of an interference between the uses of overlying landowners upon their overlying lands domestic use is to be allowed before any other use.

13. Means of Use are Immaterial between Overlying Landowners. The means by which water is used between overlying landowners upon their overlying lands are immaterial, so long as the result is not an excessive use. Tunnels, wells, open-cuts, pumps, are all legitimate means of using the water. The means of use or mode of enjoyment may be changed so long as the change does not invade the rights of any opposing person. Changes injuring persons not parties to the litigation or contest are immaterial; being possessory rights. valid against everybody except the party whose right is infringed by them, although invalid when contested by him within the prescriptive period.

14. Extraction of Water for purpose of Drainage between Overlying Landowners. Drainage of overlying land interfering with the underground water-supply, although without use of the water by the party causing the drainage, where the drainage is done for the purpose of removing the water from the land so as to keep it dry, is a proper use of the land as against any other overlying landowner; provided that, in the sound discretion of the trial court or jury, it is done in a reasonable manner, and the deterioration of the underground water-supply in the complainant's land thereby caused does not proceed to an excessive degree under all the facts and circumstances of the case.

15. Extraction of Water from Mines between Overlying Landowners. Mining may, to a reasonable degree, deplete the underground water supply under the principles in the preceding section, and where a mine drains underground water from agricultural land, the test between the miner and the 
agriculturist is whether the depletion caused by the mine is more than should reasonably be put up with by the agriculturist, in the sound discretion of the trial court or jury.

\section{Possessory Rights in Underground Water.}

16. Possessory Rights separate from Overlying Land. Possessory rights in underground water exist where two or more appropriators are doing acts above declared to be improper against overlying landowners, but where no injured overlying landowner appears in court to assert the invasion of his rights. In such cases, during the absence of the injured overlying landowner, the only question between the contesting parties is the question of possession and use. All limitations heretofore stated upon excessive taking, and all prohibitions heretofore stated of the use of underground water upon lands other than one's own overlying land, are subject to the exception that, between possessory claimants or appropriators alone, title to land is immaterial, and the place, means, manner and purpose of use are likewise immaterial.

17. Possessory Rights, Classification of. Possessory rights in underground water may exist between appropriators in the following cases: (a) Where neither claimant is an overlying landowner; (b) Where one claimant is not an overlying landowner and the other claimant is an overlying landowner using the water off of his overlying land; (c) Where both claimants are overlying landowners using the water off of their overlying lands.

18. Priority Governs between Possessory Rights. As between possessory rights, first in time of use is first in right, upon the same conditions as to posting notice, diligence, completion of work, beneficial use, and change of use. as in the case of appropriations of surface streams.

\section{Between Overlying Landowners and Possessory Claimants.}

19. Rights of Overlying Landowners are Paramount to Possessory Rights. Until ripened by prescription, possessory rights in percolating water are valid only between possessory claimants among themselves. The right of every overlying landowner, whether using the water or not, to have continuance of supply in and upon his own overlying land, is paramount 
to all possessory rights, and possessory rights will be defeated at any time, before prescription has arisen, by a suit of an overlying landowner (or landowners jointly) to protect the supply so far as it is or may be now or in the future beneficial to his (or their) own overlying land, or by a use thereof later put into operation by him or them, upon his or their overlying land.

20. Priority of Appropriation Gives No Right against an Overlying Landowner's Use of His Own Land. Priority of use or of appropriation of itself gives no right against an overlying landowner with respect to the use of his overlying land by means of the underground water supply therein. First in time is not first in right to underground water against use of overlying land by an overlying landowner. No exclusive right or monopoly in underground water will be permitted, by mere priority of use, to defeat the use of one's own overlying land.

21. Possessory Rights for Distant Land. Underground water may be taken to distant land between possessory claimants, and also against an overlying landowner so far as the taking will not impair complainant's overlying land or its value or its water-supply or its use. present or future; but the water cannot, against the protest of an overlying landowner, be taken to distant land when to do so would cause such impairment, (except as in clauses 23 to 25 below stated.) Underground water may not, against the protest of an overlying landowner thus impaired, be used upon a distant tract merely because the owner of the distant tract also owns overlying land. Where water is taken for use off of the land of the taker or beyond a watershed it is of itself a wrong toward any overlying landowner showing such impairment, even though not himself actually using the water, and there is no question of reasonableness where a distant use is contested by a local overlying landowner. Questions of reasonable use arise only between overlying landowners claiming in respect to the use of their own overlying lands alone. Diminution of pressure or of water-plane, for distant use, is not per se wrongful, but is wrongful where it causes such impairment. The burden of proof is upon the distant taker to show that he does not cause the impairment in this clause and the next following clause mentioned. 
22. Extraction of Water for Sale. Underground water may be carried off of the overlying land for sale as between possessory claimants, and also against an overlying landowner so far as the taking does not impair claimant's overlying land or its value or its water-supply or its use, present or future; but sale of water, not being a taking for use on the overlying land of the taker, is not lawful so far as it would cause such impairment to protesting overlying landowners. Pumping to supply other parties is not a permissible use of one's land to such detriment of a neighbor, except as in the following clauses specified.

23. Exceptions. The owner of the paramount title (the overlying landowner) may be barred of the assertion of his right by grant, condemnation or prescription, and may be barred of equitable relief, even though without losing his right, by laches, suffering the water to be devoted to public use, or the other defenses to equitable relief. Where water has been taken to supply the public and the public has become dependent thereon in such a way that public hardship would result from impairing its supply, and the complainant stood by while this was being accomplished, having cause to believe that it would affect his own underground water-supply, an injunction will be refused, and complainant's relief will consist in such damages as he may prove.

24. Declaration of Overlying Right against Possessory Right. While the overlying landowner has the paramount right against the possessory claimant to the supply under his own land, whether using the water or not, yet if not using the water the overlying landowner's remedy is by a decree declaring his right to begin use upon his overlying land at his convenience thereafter, but not enjoining the possessory claimant until the overlying landowner's use of his overlying land should thereafter begin, or his overlying land in other ways suffer actual present damage. The decree will provide that if the complaining overlying landowner does not use the water upon his overlying land and he suffers no actual present damage, the possessory claimant may take all the regular underground water-supply to distant land until the complaining overlying landowner is prepared to use it upon his overlying land and begins to do so, or otherwise to suffer actual present damage. 
25. Prescription. Possessory rights to underground water may ripen into prescriptive rights by continuous adverse use upon the same terms as prescriptive rights to surface streams and then are no longer subordinate to the rights of such overlying landowners as become barred by the prescription. Notice of the adverse use must be shown by the prescriptive claimant to have come to the overlying landowner at the beginning of the prescriptive period, but knowledge of the taking and of a perceptible effect upon the underground water-supply of the overlying landowner are presumptive evidence of notice of the adverse character of the taking.

San Francisco, Cal.

SAMUEI, C. WIEI. 